慶應義塾大学学術情報リポジトリ

Keio Associated Repository of Academic resouces

\begin{tabular}{|c|l|}
\hline Title & Sterol metabolism in insects : dealkylation of phytosterol to cholesterol \\
\hline Sub Title & \\
\hline Author & 池川, 信夫(Ikekawa, Nobuo) \\
& $\begin{array}{c}\text { 森崎, 益雄(Morisaki, Masuo) } \\
\text { 藤本, 善徳(Fujimoto, Yoshinori) }\end{array}$ \\
\hline Publisher & 共立薬科大学 \\
\hline Publication year & 1993 \\
\hline Jtitle & $\begin{array}{l}\text { 共立薬科大学研究年報 (The annual report of the Kyoritsu College of } \\
\text { Pharmacy). No.38 (1993. ),p.64- 64 }\end{array}$ \\
\hline JaLC DOI & \\
\hline Abstract & \\
\hline Notes & 抄録 \\
\hline Genre & Technical Report \\
\hline URL & https://koara.lib.keio.ac.jp/xoonips/modules/xoonips/detail.php?koara_id=AN00062898-0000003 \\
& $8-0064$ \\
\hline
\end{tabular}

慶應義塾大学学術情報リポジトリ(KOARA)に掲載されているコンテンツの著作権は、それぞれの著作者、学会または出版社/発行者に帰属し、その権利は著作権法によって 保護されています。引用にあたっては、著作権法を遵守してご利用ください。

The copyrights of content available on the KeiO Associated Repository of Academic resources (KOARA) belong to the respective authors, academic societies, or publishers/issuers, and these rights are protected by the Japanese Copyright Act. When quoting the content, please follow the Japanese copyright act. 


\title{
Sterol Metabolism in Insects : Dealkylation of Phytosterol to Cholesterol
}

\author{
Nobuo IKeKawa**, Masuo Morisaki and Yoshlnori Fujimoto*** \\ 池川信夫、森崎益雄、藤本善徳
}

Insects obtain indispensable sterol by the modification of $\mathrm{C}-24$-alkylated dietary sterols. Since this process is extremely important for insects, they have employed a diversified enzyme system with an excellent ability to dealkylate a variety of phytosterols, regardless of whether the C-24-alkyl group is methyl or ethyl, whether the stereochemistry at $\mathrm{C}-24$ is $R$ or $S$, and whether the $\mathrm{C}-22$ double bond is present or absent. The dealkylation of phytosterol is carried out by three successive reactions: dehydrogenation, epoxidation, and epoxide fragmentation. The resulting desmosterol is eventually hydrogenated to cholesterol. The crucial step is fragmentation of epoxide, and this reaction appears to occur in a highly stereoselective manner, as evidenced from the pro- $S$ - and pro- $R-$ methyl groups of fucosterol $(24 R, 28 R)$-epoxide being transformation to the $(Z)$ - and (E)-methyl groups, respectively, of desmosterol. Experimental evidences of all these results obtained by the use of the silkworm Bombyx mori have been presented. Also discussed are sterol structure requirement of $B$. mori, and inhibitors of sterol metabolism in insects.

* 本報告は Acc. Chem. Res., 26, 139-146，（1993）に発表。

**いわき明星大学・理工学部

*** 東京工業大学・理学部 